TITLE:

\title{
Comparison of the decomposition behaviors of hardwood and softwood in supercritical methanol
}

$\operatorname{AUTHOR}(S)$ :

Minami, Eiji; Saka, Shiro

\section{CITATION:}

Minami, Eiji ...[et al]. Comparison of the decomposition behaviors of hardwood and softwood in supercritical methanol. Journal of Wood Science 2003, 49: 0073-0078

\section{ISSUE DATE:}

2003-02

URL:

http://hdl.handle.net/2433/250167

\section{RIGHT:}

This is a post-peer-review, pre-copyedit version of an article published in Journal of Wood Science. The final. authenticated version is available online at: $h$ ttp://dx.doi.org/10.1007/s100860300012: This is not the published version. Please cite only the published version.; この論文は出版社版でありません。引用の際には出版社版をご確認ご利用くだ さい。 


\section{Title page}

\section{Original article}

Title

Comparison of the decomposition behaviors of hardwood and softwood in supercritical methanol

Authors

Eiji Minami • Shiro Saka

Eiji Minami $\cdot$ Shiro Saka $(\bowtie)$

Department of Socio-Environmental Energy Science, Graduate School of Energy Science, Kyoto University, Yoshida-honmachi Sakyo-ku, Kyoto, 606-8501, Japan

Tel/Fax: +81-(0) 75-753-4738

E-mail: saka@energy.kyoto-u.ac.jp

*This study was presented in part at the 45th Lignin Symposium in Ehime, Japan, Oct. 26-27, 2000 and the 51st Annual Meeting of the Japan Wood Research Society in Tokyo, Japan, April 2-4, 2001.

Keywords : Chemical conversion $\cdot$ Supercritical methanol $\cdot$ Hardwood $\cdot \operatorname{softwood} \cdot$ Lignin $•$ Cellulose 
Abstract: The chemical conversion of Japanese beech (Fagus crenata Blume) and Japanese cedar (Cryptomeria japonica D. Don) woods in supercritical methanol was studied by using the supercritical fluid biomass conversion system with a batch-type reaction vessel. As a result, at a condition of $270^{\circ} \mathrm{C}-27 \mathrm{MPa}$, beech wood was decomposed and liquefied to a greater extent than cedar wood, and the difference observed was considered to be mainly originated from intrinsic properties in lignin structure between hardwood and softwood. However, at $350^{\circ} \mathrm{C}-43 \mathrm{MPa}$, such a difference was not observed and over $90 \%$ of both beech and cedar woods were effectively decomposed and liquefied after 30 min treatment. This result indicates that the supercritical methanol treatment is expected as an efficient tool to convert the woody biomass into the lower molecular products such as liquid fuels and useful chemicals. 


\section{Introduction}

Due to the global warming by the excessive use of fossil resources, renewable resources of biomass will become more important in the future as an alternative of fossil resources. In addition, according to our recent investigation, ${ }^{1} 240$ million tons of biomass wastes such as the lignocellulosics are annually generated in Japan in which 65 million tons are not used effectively. Therefore, the technology which converts them to the valuable liquid fuels and chemicals will become important to solve energy and environmental problems. On the other hand, recently, supercritical fluid has been considered to be an attractive alternative in science and technology as a new reaction field..$^{2-5}$

Therefore, the supercritical water $\left(>374^{\circ} \mathrm{C},>22.1 \mathrm{MPa}\right)$ treatment of biomass resources has been studied to convert them to useful chemicals by various groups. ${ }^{2,4,6,7}$ Consequently, the pyrolysis was found to be depressed to some extent by controlling the reaction conditions. ${ }^{4}$ However, hydrolysis products such as glucose were further decomposed rapidly in supercritical water due to its high critical temperature. On the other hand, in case of methanol, its critical temperature $\left(T_{\mathrm{c}}=239^{\circ} \mathrm{C}\right)$ and critical pressure $\left(P_{\mathrm{c}}=8.09 \mathrm{MPa}\right)$ which are lower than those of water can offer the milder conditions of the reaction. McDonald et al. have reported that the supercritical methanol extraction of western red cedar (Thuja plicata D. Don) at $350^{\circ} \mathrm{C}-28 \mathrm{MPa}$ yielded $70 \%$ of extracted oil in which approximately $5 \%$ of products was identified as phenols and levoglucosan. ${ }^{8}$ Furthermore, Poirer et al. have also studied the supercritical methanol extraction of aspen (Populus tremuloides Michx) and the effects of three variables of temperature, pressure and flow rate of the solvent on oil yield have been investigated by statistical analysis. ${ }^{9}$ However, decomposition behaviors of each component in wood, and its cell wall components of cellulose, hemicelluloses and lignin in supercritical methanol remained unclear. 
Therefore, Ishikawa and Saka have studied the decomposition behaviors of cellulose samples of avicel (microcrystalline cellulose), cotton linter and dissolving. ${ }^{10}$ In this study, thus the decomposition behaviors of woody biomass in supercritical methanol were studied focusing on the wood cell wall components, especially on lignin from hardwood and softwood. The advantages of this study are that the methanol with reaction products can be used as liquid fuel because methanol itself is a good fuel. Furthermore, the liquid fuel from only biomass resources can be created by using bio-methanol as the supercritical solvent synthesized by pyrolysis of biomass resources.

\section{Materials and methods}

Supercritical methanol treatment

As woody biomass samples, wood flours (80 mesh pass) from Japanese beech (Fagus crenata Blume) as hardwood and Japanese cedar (Cryptomeria japonica D. Don) as softwood were used for supercritical methanol treatment. Besides, HPLC grade of methanol was used as a solvent. Supercritical methanol treatment was conducted by using a biomass conversion system with a batch-type reaction vessel described elsewhere. ${ }^{6,7,10}$ The reaction vessel with a $5 \mathrm{ml}$ volume is made of Inconel-625. This system can cover a range in pressure and temperature up to $280 \mathrm{MPa}$ and $500^{\circ} \mathrm{C}$, respectively, with a constant density of $0.79 \mathrm{~g} / \mathrm{ml}$. To start a treatment, approximately $4.9 \mathrm{ml}$ of methanol was fully fed with $150 \mathrm{mg}$ of the wood flour into the $5 \mathrm{ml}$ reaction vessel and then its reaction vessel was immersed into the tin bath preheated at an adequate temperature and maintained under supercritical conditions $\left(>239^{\circ} \mathrm{C},>8.09 \mathrm{MPa}\right)$ for 1 to $30 \mathrm{~min}$. After an adequate reaction time, the reaction vessel was moved into the water bath to quench the reaction. The obtained reaction mixture was then filtrated with $0.2 \mu \mathrm{m}$ membrane 
filter to separate methanol-soluble portion and methanol-insoluble residue.

Analytical methods

The methanol-soluble portion was directly analyzed by high performance liquid chromatography (HPLC) carried out with Shimadzu LC-10A under the following conditions: 1) column; STR ODS-II, flow rate; $1.0 \mathrm{ml} / \mathrm{min}$, eluent; $\mathrm{CH}_{3} \mathrm{OH} / \mathrm{H}_{2} \mathrm{O}=20 / 80 \rightarrow 100 / 0$ (0-60min), detector; $\mathrm{UV}_{280 \mathrm{~nm}}$, temperature; $40^{\circ} \mathrm{C} .2$ ) column; ULTRON PS-80P, flow rate; $0.8 \mathrm{ml} / \mathrm{min}$, eluent; $\mathrm{H}_{2} \mathrm{O}$, detector; refractive index detector (RID), temperature; $40^{\circ} \mathrm{C}$. Some reaction products were separated by using the HPLC system and analyzed by proton nuclear magnetic resonance $\left({ }^{1} \mathrm{H}-\mathrm{NMR}\right)$ spectroscopy, in which its spectra were recorded in $\mathrm{CDCl}_{3}$ by Varian AC-300 (300MHz) spectrometer with tetramethylsilane as an internal standard. In addition, gel permeation chromatography (GPC) was also carried out for the methanol-soluble portion with Shimadzu LC-10A under the following conditions: column; Shodex KF-801 connected with KF-802, KF-802.5 and KF-803 in the series, flow rate; $0.6 \mathrm{ml} / \mathrm{min}$, eluent; tetrahydrofuran (THF), detector; $\mathrm{UV}_{280 \mathrm{~nm}}$, temperature; $50^{\circ} \mathrm{C}$.

For the methanol-insoluble residue, the lignin content was determined by Klason lignin analysis and acid-soluble lignin included determined by the ultraviolet spectroscopy. ${ }^{11}$ The yield of the nitrobenzene oxidation products of the lignin in the alkaline solution was also determined for the methanol-insoluble residue according to the described methods. ${ }^{12}$ In addition, the amounts of constituent monosaccharides in the methanol-insoluble residue were also determined by the HPLC analysis for the clear filtrate from acid hydrolyzates in the Klason lignin determination under the conditions mentioned above. The cellulose and hemicelluloses contents in the methanol-insoluble residue were, then, estimated, based on the amounts of glucose and other monosaccharides, respectively. 


\section{Results and Discussion}

Decomposition behaviors

Figure 1 shows the changes in the methanol-insoluble residues of beech and cedar woods as treated in supercritical methanol at various conditions. In the low temperatures of 255 ${ }^{\circ} \mathrm{C}$ and $270^{\circ} \mathrm{C}$, the amount of the residue remained constant after 5 min treatment. For example, about $65 \%$ of beech wood remained to be methanol-insoluble at $270^{\circ} \mathrm{C}-27 \mathrm{MPa}$. However, at the high temperature of $350^{\circ} \mathrm{C}$, decomposition of woods proceeded as the treatment was extended, and finally more than $90 \%$ of woods was decomposed and liquefied in methanol after 30min. Only a difference observed between beech and cedar was that beech wood was slightly easier to be liquefied than cedar.

Figure 2 shows the changes of the chemical composition of cellulose, hemicelluloses and lignin in the residues of beech and cedar woods as treated in supercritical methanol at $270{ }^{\circ} \mathrm{C}$ -27MPa. It is clear that lignin of beech was liquefied to a greater extent than that of cedar. Furthermore, hemicelluloses of both woods were also decomposed slightly in methanol, whereas cellulose was not under the given condition. Therefore, the decomposition of lignin mainly contributes to the liquefaction of beech and cedar woods under supercritical methanol.

At a condition of $350^{\circ} \mathrm{C}-43 \mathrm{MPa}$ (Figure 3), however, all three components of cellulose, hemicelluloses and lignin were decomposed and liquefied effectively in methanol in both cases. On lignin, however, its residues about 1-3\% on the original wood basis remained constant after 3min treatment. This suggests that these residues must have specific structure of lignin stable in supercritical methanol. 
Decomposition of cellulose and lignin

Assuming that the decomposition of cellulose and lignin in supercritical methanol is the pseudo-first-order reaction, their decomposition rate constant $(\kappa)$ in beech and cedar woods was evaluated by the following equation:

$$
X=\mathrm{e}^{-\kappa t} \times 100 \text { (wt\% on the original cellulose or lignin basis) }
$$

where $X$ is the residue of cellulose or lignin and $t$ is the treatment time (sec). Figure 4 shows the obtained Arrhenius plots for the $\kappa s$ of cellulose and lignin in the cedar and beech woods. It is apparent that the $\kappa$ of lignin in beech is larger than that in cedar at any range of temperatures studied which, in turn, larger than that of cellulose, especially at around $300^{\circ} \mathrm{C}$.

However, the $\kappa$ of cellulose in both woods was almost equal each other and increased above $300{ }^{\circ} \mathrm{C}$, which is about $60^{\circ} \mathrm{C}$ higher than the critical temperature $\left(T_{\mathrm{c}}\right)$ of methanol, as in Figure 4. This trend is similar to that of avicel, microcrystalline cellulose, studied in a previous work. ${ }^{10}$ However, in supercritical water treatment, Sasaki et al. reported that the $\kappa$ of the cellulose is drastically increased around the $T_{\mathrm{c}}$ of water. ${ }^{13}$ This discrepancy has not been clear yet.

Figure 4 shows further that the $\kappa$ of cellulose in woods is smaller than that of avicel at an elevated temperature. This observed difference is possibly originated from that in the fibrillar structures between these samples; avicel is in a powder form, while cellulose in wood is in a fiber from. Therefore, avicel is more accessible to methanol molecules than cellulose in woods. Actually, Ishikawa and Saka ${ }^{10}$ have reported that the cotton linter and dissolving pulp are more difficult to be liquefied in supercritical methanol than avicel.

On the decomposition of lignin, the $\kappa$ of lignin in beech is larger than that of cedar as in 
Figure 4. This observed difference would be mainly originated from intrinsic properties in lignin structure between hardwood and softwood. Figure 5 shows that the yield of the nitrobenzene oxidation products, which is a measure of the number of the ether linkages in lignin, decreased for the methanol-insoluble residue of woods as the supercritical treatment was extended. Therefore, the methanol-insoluble residue becomes lesser in the ether linkages such as $\beta-\mathrm{O}-4$ and $\alpha-\mathrm{O}-4$ linkages in lignin. In addition, the lignin model compound study indicated that the condensed linkages of lignin such as 5-5 and $\beta-1$ linkages are stable during supercritical treatment of methanol, whereas the $\beta$-ether and $\alpha$-ether linkages are rapidly cleaved. ${ }^{14,15}$ Therefore, it is suggested that the cleavage of ether linkages mainly contributes to the decomposition of lignin. This further indicates that the lignin which is rich in the ether linkages is more easily depolymerized than the condensed types of lignin in supercritical methanol. Hardwood lignin which is known to have more ether linkages is, therefore, readily depolymerized and liquefied, compared with softwood lignin, as observed in Figure 4.

Based on these lines of evidence, the treatment temperatures over $300^{\circ} \mathrm{C}$ would be necessary to decompose beech and cedar woods effectively. Besides, at $370-380^{\circ} \mathrm{C}$, the thermal cracking of methanol is reported to be occurred. ${ }^{16}$ Therefore, it can be concluded that the appropriate treatment temperature of wood is about $350^{\circ} \mathrm{C}$.

Decomposed products of cellulose and lignin

Cellulose-derived products in methanol-soluble portion were also studied. As a result, the main monomeric products from cellulose of both beech and cedar woods were identified to be methyl- $\beta$-D-glucoside, methyl- $\alpha$-D-glucoside and levoglucosan by HPLC analysis. Furthermore, 5-hydroxymethylfurfural and furfural were also found in methanol-soluble 
portion of both woods as minor products. According to the decomposition pathway proposed by Ishikawa and Saka, ${ }^{10}$ methanolysis of cellulose in supercritical methanol results in methylated cellotriose and methylated cellobiose, which are converted to methyl $\alpha$ - and $\beta$-D-glucosides. Subsequently, these are anomerized each other, and under the prolonged treatment, decomposed further to the other products such as levoglucosan and 5-hydroxymethylfurfural. Therefore, the main decomposition pathway of cellulose in woods must be the same as that of avicel in supercritical methanol.

Figure 6 shows the yield changes of methyl $\alpha$-D-glucoside (MG- $\alpha$ ), methyl $\beta$-D-glucoside (MG- $\beta$ ) and levoglucosan (LG) on the original cellulose basis as the supercritical treatment was extended at $350^{\circ} \mathrm{C}-43 \mathrm{MPa}$. The results obtained are very similar between beech and cedar, and their yields increase gradually with the treatment time extended. However, these on the methanol-soluble portion basis were almost constant in proportion on every treatment time.

On the lignin-derived products in methanol-soluble portion, the main monomeric products were identified to be guaiacol, coniferyl alcohol and its $\gamma$-methyl ether as guaiacyl lignin-derived products from both woods, 2,6-dimethoxyphenol, sinapyl alcohol and its $\gamma$-methyl ether as syringyl lignin-derived products from beech wood. Figure 7 shows the yields of coniferyl alcohol (CA), sinapyl alcohol (SA) and their $\gamma$-methyl ethers (CA- $\gamma$ and SA- $\gamma$ ) on the original lignin basis under the conditions of $270^{\circ} \mathrm{C}-27 \mathrm{MPa}$. Coniferyl alcohol and sinapyl alcohol appeared at an early stage of the treatment, then decreased. In turn, $\gamma$-methyl ethers of coniferyl alcohol and sinapyl alcohol appeared to be comparatively stable in supercritical methanol. This pathway has been already elucidated by the lignin model compound study and conversions of coniferyl alcohol and sinapyl alcohol into their $\gamma$-methyl ethers are considered to be due to the acidic character of the supercritical methanol. ${ }^{14}$ After all, the maximal total yields of the methanol-soluble compounds from beech and cedar woods were, respectively, 89 and 
$53 w t \%$ on the lignin basis.

It was demonstrated in the lignin model compound study ${ }^{14,15}$ that the condensed types of linkages such as 5-5 and $\beta-1$ are stable during the supercritical methanol treatment, while the ether linkages such as $\beta-\mathrm{O}-4$ and $\alpha-\mathrm{O}-4$ are readily cleaved. Therefore, the methanol-insoluble residues in Figure 7 must be rich in the condensed types of linkages. In addition, the higher proportion of the methanol-insoluble residues in cedar is in a good agreement with the fact that softwood is more condensed than hardwood in their lignin structure.

Molecular weight distribution of the methanol-soluble portion

The main monomeric products in the methanol-soluble portion were identified as discussed above. However, the minor products described by the other products in Figures 6 and 7 are not clearly identified. Therefore, the molecular weight distribution of the methanol-soluble portion was studied by GPC analysis. Figure 8 shows the obtained GPC chromatograms of beech and cedar woods as treated in supercritical methanol at $350^{\circ} \mathrm{C}-43 \mathrm{MPa}$. It is apparent that the distribution in beech wood is similar to that in cedar in a range between 100 and 3,000, in their molecular weight. Furthermore, the mean molecular weight decreased in both woods as the treatment was extended. Therefore, the products liquefied in methanol would not be condensed each other and decomposed further into the lower molecular weight products in supercritical methanol. 


\section{Conclusion}

The chemical conversion of beech and cedar woods in supercritical methanol was studied by using the supercritical fluid biomass conversion system. The condition for the chemical conversion of woods was optimized to be $350^{\circ} \mathrm{C}-43 \mathrm{MPa}$. Under this condition, beech wood was decomposed to a greater extent than cedar wood, but in both cases over $90 \%$ of woods was successfully decomposed and liquefied in methanol. However, about 1-3\% of lignin on the whole wood basis was found to remain methanol-insoluble, which would be rich in the condensed types of linkages stable in supercritical methanol, as demonstrated in a study with lignin model compounds. ${ }^{14,15}$ 


\section{Acknowledgments}

This research has been done under the research program for development of technologies for establishment of eco-system based on recycling in rural villages for the 21st century from the Ministry of Agriculture, Forestry and Fisheries, Japan and by a Grant-in-Aid for Scientific Research (B)(2) (No.12460144, 2001.4-2003.3) from the Ministry of Education, Culture, Sports, Science and Technology, Japan. 


\section{References}

1. Minami E, Saka S (2001) Quantity of biomass in Japan (in Japanese). In: Saka S (ed) Biomass $•$ Energy $•$ Environment. Industrial Publishing \& Consulting, Inc., Tokyo, pp 61-103

2. Antal MJ Jr., Mok WSL, Richards GN (1990) Four-carbon model compounds for the reactions of sugars in water at high temperature. Carbohydr. Res. 199: 111-115

3. Sakaki K (1993) Supercritical fluid choromatographic separation of fatty acid methyl esters on aminopropyl-bonded silica stationary phase. J. Chromatography 648: 451-457

4. Sasaki M, Fang Z, Fukushima Y, Adschiri T, Arai K (2000) Dissolution and hydrolysis of cellulose in subcritical and supercritical water. Ind. Eng. Chem. Res. 39: 2883-2890

5. Saka S, Kusdiana D (2001) Biodiesel fuel from rapeseed oil as prepared in supercritical methanol. Fuel 80: 225-231

6. Saka S, Ueno T (1999) Chemical conversion of various celluloses to glucose and its derivatives in supercritical water. Cellulose 6: 177-191

7. Saka S, Konishi R (2001) Chemical conversion of biomass resources to useful chemicals and fuels by supercritical water treatment. In: Bridgwater AV (ed) Progress in Thermochemical Biomass Conversion. Blackwell Sci., Oxford, pp1338-1348

8. McDonald EC, Howard J, Bennett B (1983) Chemicals from forest products by supercritical fluid extraction. Fluid Phase Equilib. 10: 337-344

9. Poirier MG, Ahmed A, Grandmaison JL, Kaliaguine CF (1987) Supercritical gas extraction of wood with methanol in a tubular reactor. Ind. Eng. Chem. Res. 26: $1738-1743$

10. Ishikawa Y, Saka S (2001) Chemical conversion of cellulose as treated in supercritical methanol. Cellulose 8: 189-195 
11. Dence CW (1992) The Determination of Lignin. In: Lin SY, Dence CW (eds) Methods in Lignin Chemistry. Springer-Verlag, Berlin, pp 33-39

12. Chen CL (1992) Nitrobenzene and Cupric Oxide Oxidations. In: Lin SY, Dence CW (eds) Methods in Lignin Chemistry. Springer-Verlag, Berlin, pp 301-312

13. Sasaki M, Kabyemela B, Malaluan R, Hirose S, Takeda N, Adschiri T, Arai K (1998) Cellulose hydrolysis in subcritical and supercritical water. J. Supercritical Fluids 13: 261-268

14. Tsujino J, Kawamoto H, Saka S (2002) Reactivity of lignin in supercritical methanol studied with some lignin model compounds. Wood Sci. Tech. (in press)

15. Minami E, Kawamoto H, Saka S. Reaction behaviors of lignin in supercritical methanol as studied with lignin model compounds. J. Wood Sci. (submitted)

16. Labrecque R, Kallagulne S, Grandmalson JL (1984) Supercritical gas extraction of wood with methanol. Ind. Eng. Chem. Prod. Res. Dev. 23: 177-182. 


\section{List of Figures}

Figure 1. Changes in the residues of (a) beech and (b) cedar woods as treated in supercritical methanol at various conditions. Squares, $255^{\circ} \mathrm{C}-24 \mathrm{MPa}$; Circles, $270{ }^{\circ} \mathrm{C}-27 \mathrm{MPa}$; Triangles, $325^{\circ} \mathrm{C}-36 \mathrm{MPa}$; Crosses: $350^{\circ} \mathrm{C}-43 \mathrm{MPa}$; Pluses, $375^{\circ} \mathrm{C}-50 \mathrm{MPa}$.

Figure 2. Products composition of (a) beech and (b) ceder woods as treated in supercritical methanol at $270^{\circ} \mathrm{C}-27 \mathrm{MPa}$.

Figure 3. Products composition of (a) beech and (b) ceder woods as treated in supercritical methanol at $350^{\circ} \mathrm{C}-43 \mathrm{MPa}$.

Figure 4. Arrhenius plots for the decomposition rate constants of cellulose and lignin in beech and cedar woods in subcritical and supercritical methanol. Filled triangles, beech lignin; Filled squares, cedar lignin; Open triangles, beech cellulose; Open squares, cedar cellulose.

Figure 5. Changes in the yields of alkaline nitrobenzene oxidation products of methanol-insoluble residue in beech and cedar woods as treated in supercritical methanol at 270 ${ }^{\circ} \mathrm{C}-27 \mathrm{MPa}$.

Figure 6. The changes in the yields on the cellulose basis of cellulose-derived products in methanol-soluble portions of (a) beech and (b) cedar woods as treated in supercritical methanol at $350^{\circ} \mathrm{C}-43 \mathrm{MPa}$. MG- $\beta$, methyl- $\beta$-D-glucoside; MG- $\alpha$, methyl- $\alpha$-D-glucoside; LG, levoglucosan. 
Figure 7. The yield changes on the lignin basis of lignin-derived products in methanol-soluble portions of (a) beech and (b) cedar woods as treated in supercritical methanol at $270{ }^{\circ} \mathrm{C}-27 \mathrm{MPa}$. CA, coniferyl alcohol; CA- $\gamma$, coniferyl alcohol $\gamma$-methyl ether; SA, sinapyl alcohol; SA- $\gamma$, sinapyl alcohol $\gamma$-methyl ether.

Figure 8. GPC chromatograms of methanol-soluble portions of (a) beech and (b) cedar woods as treated in supercritical methanol at $350^{\circ} \mathrm{C}-43 \mathrm{MPa}$. (Column: Shodex KF-803 connected with KF-802.5, KF-802 and KF-801, flow rate: 0.6 ml/min, eluent: THF, detector: $U^{280 n m, ~}$ temperature: $\left.50^{\circ} \mathrm{C}\right)$. 


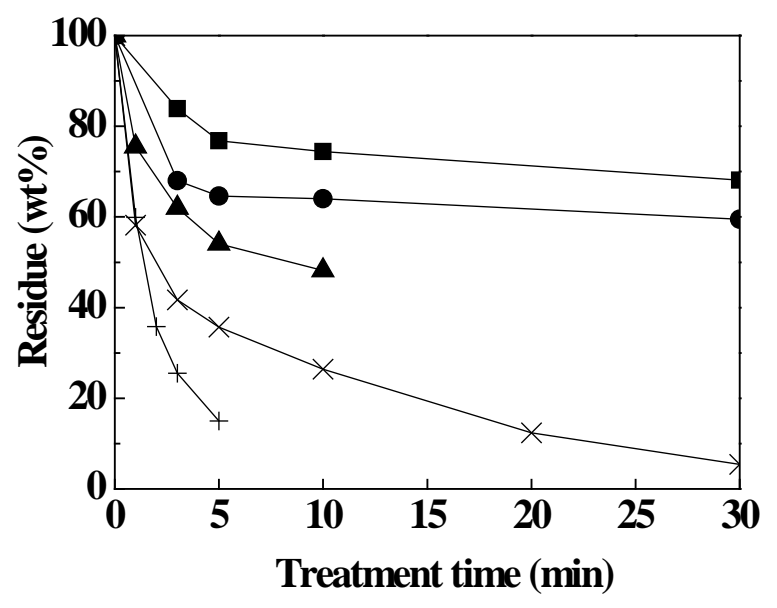

(a) Beech

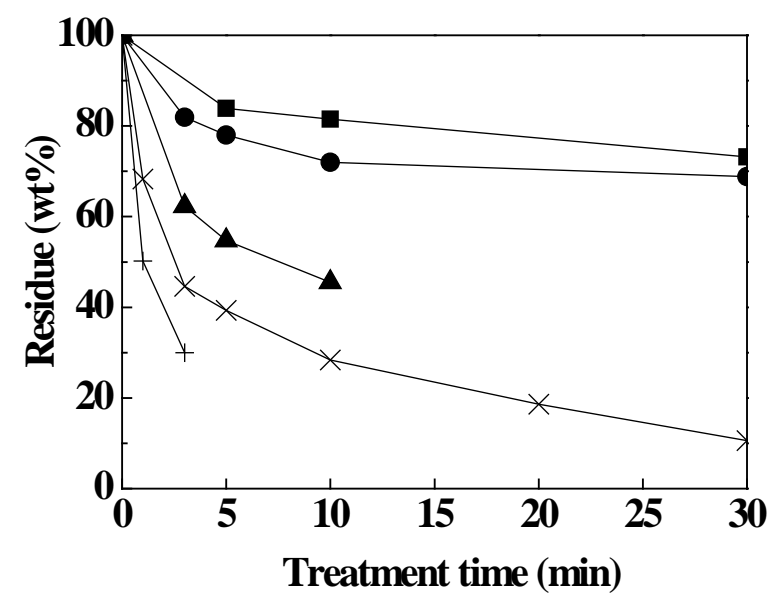

(b) Cedar 


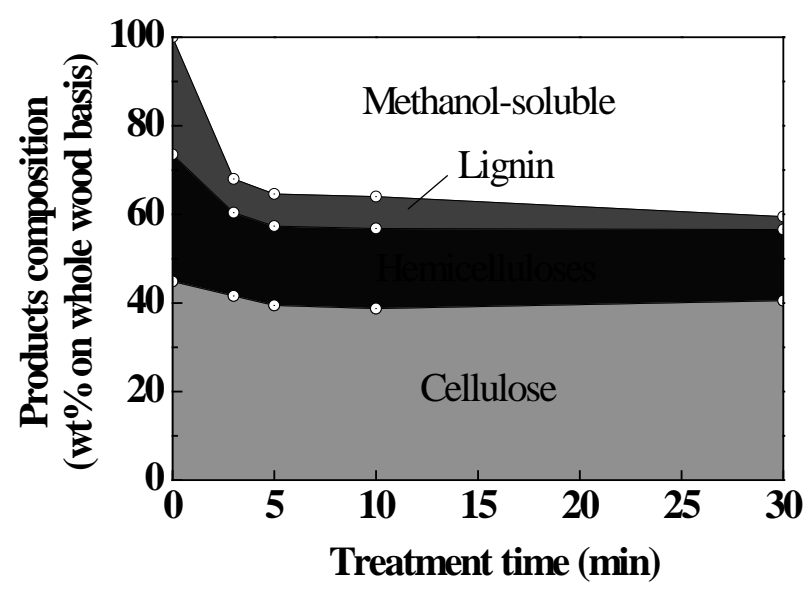

(a) Beech

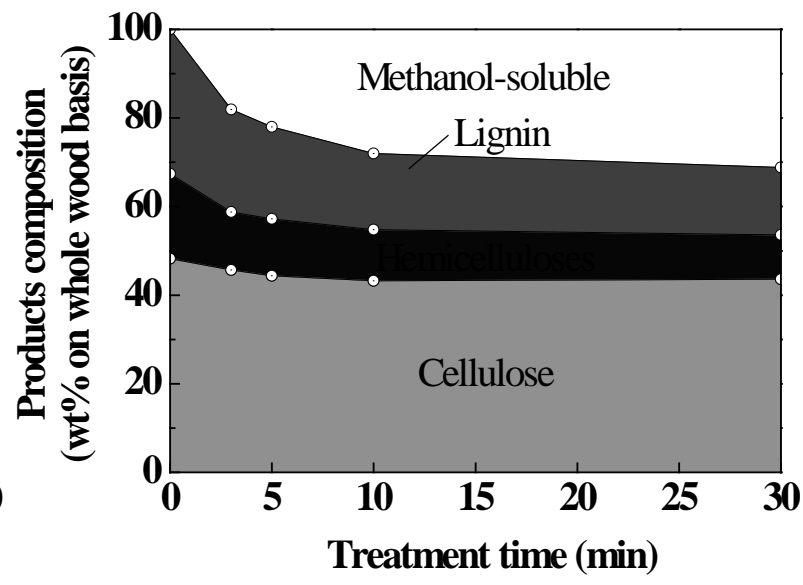

(b) Cedar 


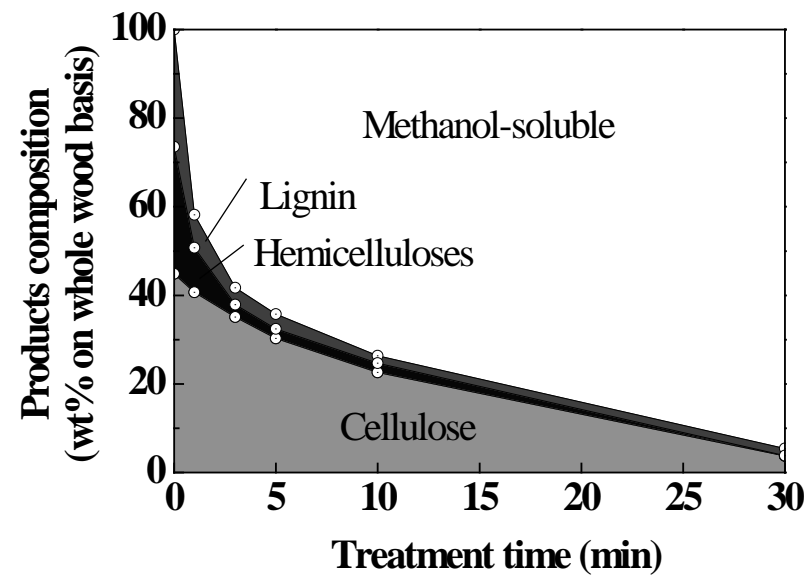

(a) Beech

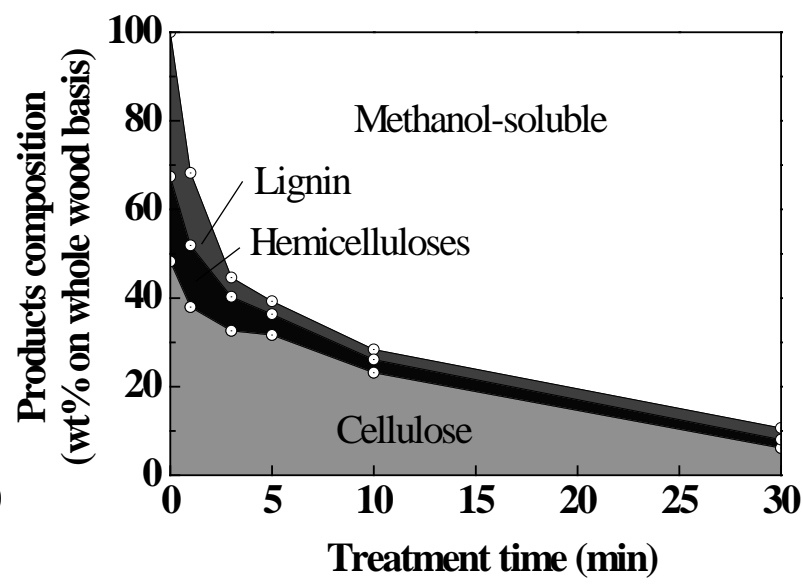

(b) Cedar 


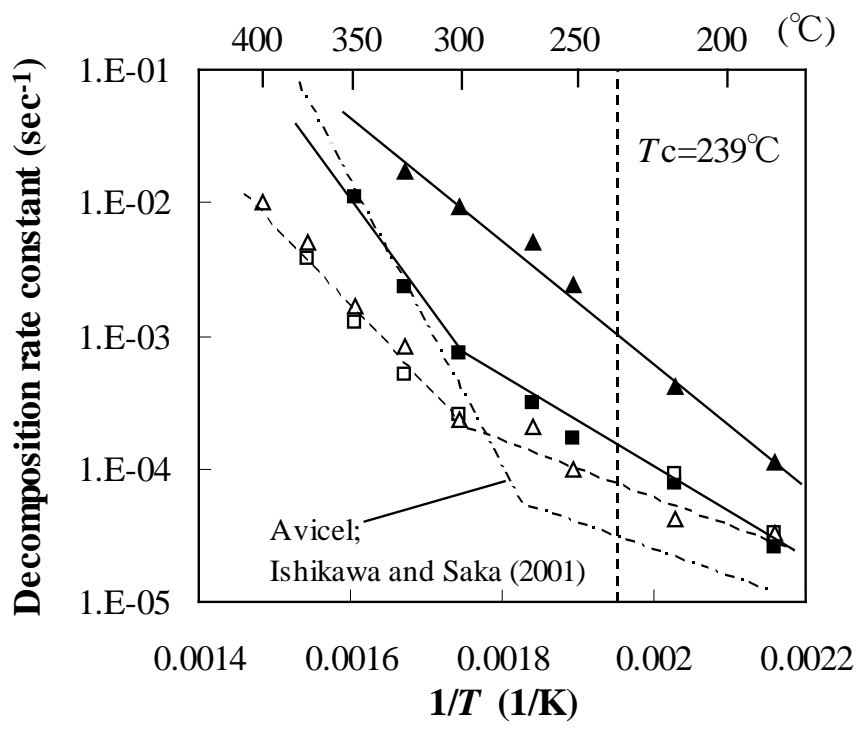




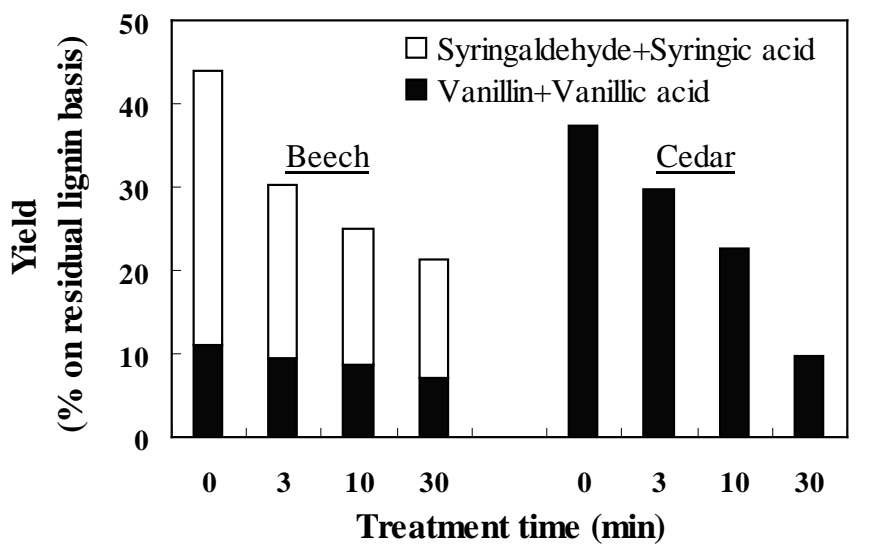




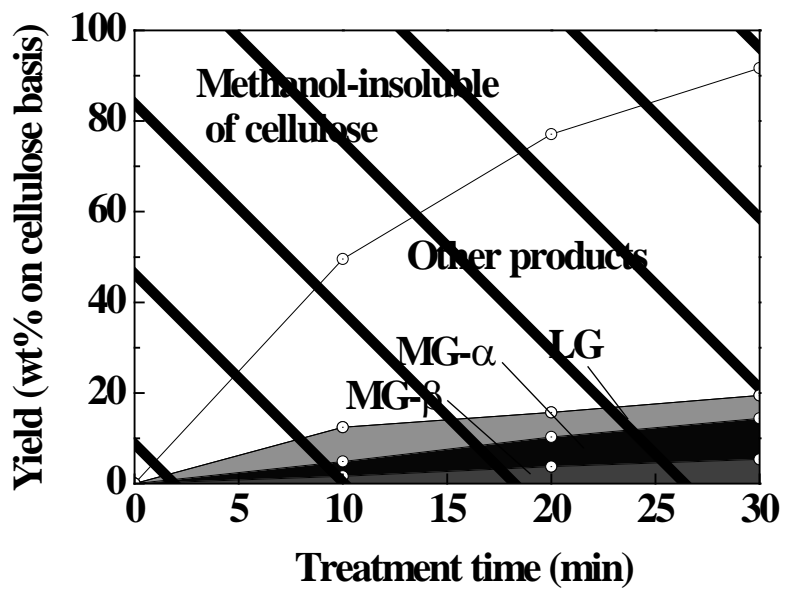

(a) Beech

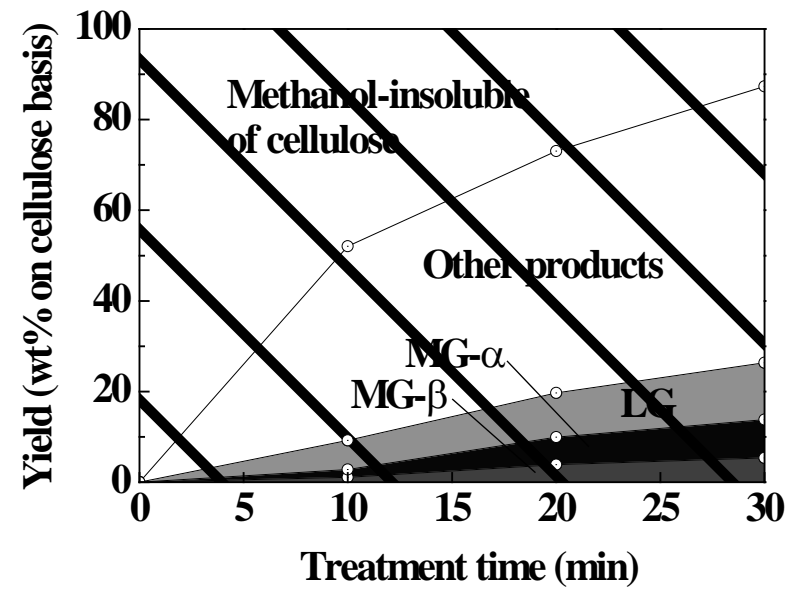

(b) Cedar 


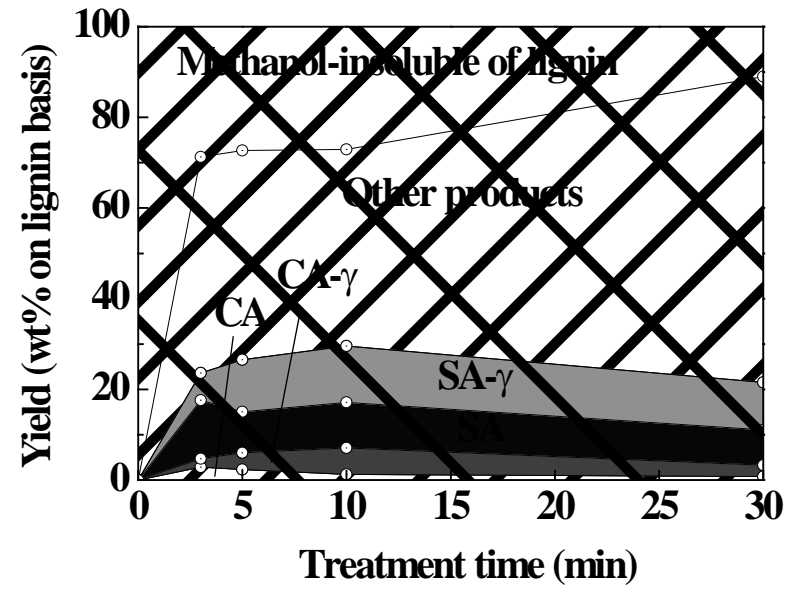

(a) Beech

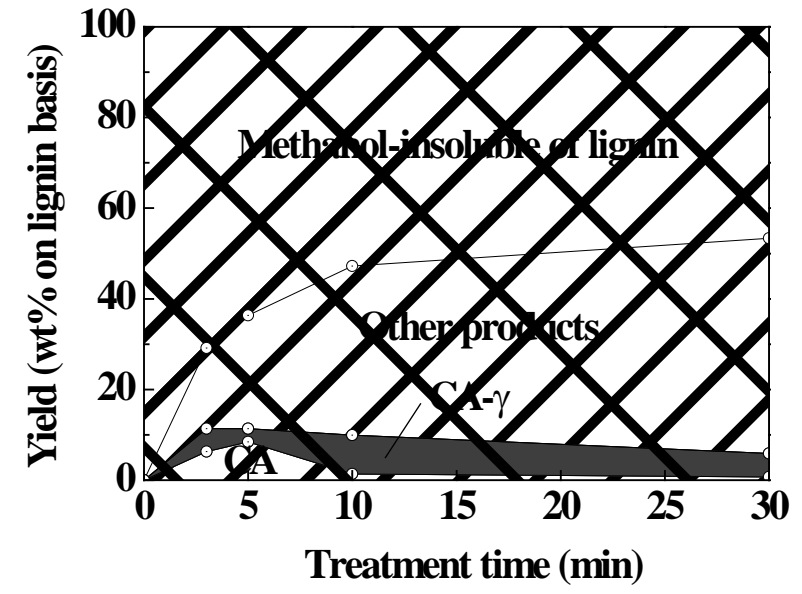

(b) Cedar 


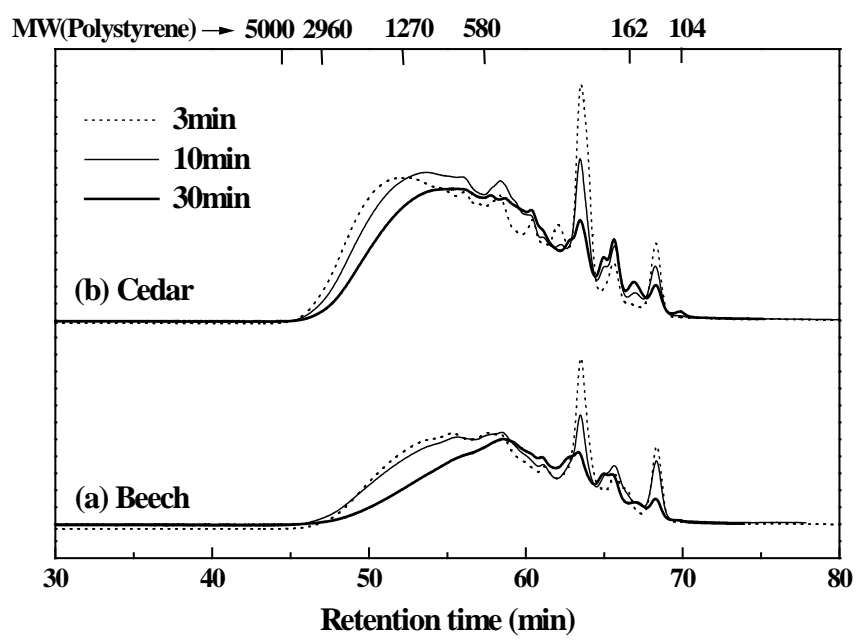

